INTERNATIONAL JOURNAL OF
ORGANIZATIONAL LEADERSHIP
ORGANIZATIONAL
INADERIIP

\title{
Strategic Leadership: A Bibliometric Analysis on Current Status and Emerging Trends
}

\author{
Yan Tao', Jiaxi He${ }^{2 *}$, Yi-fei Wang ${ }^{3}$, Hongyan $\mathrm{Ke}^{4}$ \\ ${ }^{1,2,3,4}$ Business School, Hohai University, Nanjing, Jiangsu, China \\ ${ }^{1}$ Ivey business School, Western University, Canada
}

\begin{abstract}
Keywords:

Strategic leadership, Hotspots topics, Bibliometrics,

VosViewer, HistCite

Strategic leadership has become an indispensable factor for companies to promote their development, maintain competitive advantage, and seek new opportunities. This study examines the various features of strategic leadership research by retrieving and analyzing the existing publications. The main objective of this study is to review 416 relevant papers on strategic leadership in the Web of Science core database from 1996 to 2021. With the

\section{Received}

02 December 2021

Received in revised form

15 December 2021

Accepted

18 December 2021

*Correspondence:

jxhhohai@163.com

help of HistCite and VOSviewer visual science tools, this paper first presents the research methodology and data sources to describe an overview of strategic leadership research, including growth trends, journal distribution, core authors, research institutions, and key literature. Next, this paper also finds four research strands in existing research: leader traits, CEO-TMT interface, learning and innovation, and dynamic leadership. Then, we used the keyword analysis to extract five hot topics with research value: strategic leaders, corporate governance, ethical practices, organizational learning, and organizational change and innovation. This study provides a reference for selecting a research theme and constructing a framework for strategic leadership in a comprehensive, scientific and visual way. Furthermore, it also offers the scholars map for building collaborative research networks with multiple core authors and research institutions across the globe. Therefore, they could contribute significantly to further research.
\end{abstract}

CCIKD Publishing

In the 21st century, global market competition has intensified, the business survival environment is turbulent, and the new crown pneumonia epidemic that ravaged the world in 2020 has caused a significant impact on business development. In this context, strategic leadership has gradually become an indispensable factor for companies to promote their 
development, maintain competitive advantage, and seek growth opportunities (Bergh et al., 2016). Accordingly, scholars have conducted in-depth research and exploration on the concept and structure of strategic leadership around this topic from the perspective of competencies (Glenn, 2001; Martin et al., 1996), traits (Resick et al., 2009; Waldman et al., 2004), and styles (Azbari et al., 2015; Vera \& Crossan, 2004). As a result, they have obtained rich theoretical and empirical research results.

Hosmer (1982) first clearly proposed that strategic leadership establishes an overall sense of purpose and direction in an organization to guide and integrate the formulation and implementation of corporate strategy. And then, along with the formulation and refinement of the Upper Echelon theory (Hambrick, 2007), scholars began to explore the concept and connotation of strategic leadership continuously. For example, Hambrick and Mason (1984) define strategic leadership as the variety of individual characteristics exhibited by strategic leaders. Ireland and Hitt (1999) define strategic leadership from a competency perspective as the individual ability to anticipate, envision, maintain flexibility, think strategically, and work with others to initiate changes that will create a viable future for the organization. Sosik et al. (2005) point out that strategic leadership is a series of processes that determine the degree to which organizations are effective in making fundamentally sound connections between people, technology, work processes, and business opportunities aimed at adding economic, social, and intellectual capital for shareholders, society, and employees. Academics have defined and extended the concept of strategic leadership from multiple perspectives, focusing on the subject, objectives, functions, role mechanisms, and other aspects of strategic leadership, and have conducted extensive empirical studies accordingly (Ebrahimpour Azbari et al., 2015; Jansen et al., 2009). Studies have found that strategic leadership has positive effects on improving organizational performance, promoting organizational change, and deepening organizational learning in various aspects (Agle et al., 2006; Elenkov \& Manev, 2005; Vera \& Crossan, 2004). Upper Echelon theory emphasizes executives' experience, values, and personality in decision-making. Thus, most relevant studies have focused on CEOs and TMTs (Ensley et al., 2006; Ling et al., 2008). However, this simple approach of directly defining strategic leaders as the top leaders of an organization narrows the scope of strategic leadership research and imposes limitations on its empirical studies.

Strategic leadership is a hot area of interest for both academics and practitioners. However, there are still shortcomings in the academic research, such as the lack of a unified consensus on the concept of strategic leadership and the single measurement method of strategic leadership. In addition, it is worthwhile to explore further how strategic leadership can be integrated with information technology in the context of the digital economy to take tremendous advantage of it. Therefore, to understand the field of strategic leadership as a whole, we need to (1) sort out the theoretical streams of strategic leadership and paint a research picture; (2) analyze the hot topics and development trends in the field of strategic leadership; (3) propose possible directions for future research. Therefore, this paper conducts a bibliometric analysis on strategic leadership. We searched out 416 highly relevant literature during 1996-2021 from the Web of Science core database and analyzed them with HistCite and VOSviewer.

This paper first presents the research methodology and data sources to describe an overview of strategic leadership research, including growth trends, journal distribution, core authors, 
research institutions, and key literature. Next, we depicted four research strands in existing research: leader traits, CEO-TMT interface, learning and innovation, and dynamic leadership. Then, this paper used the keyword analysis to extract five hot directions and thematic terms rich in research value: strategic leaders, corporate governance, ethical practices, organizational learning, and organizational change and innovation. Finally, we propose the outlook of strategic leadership. This paper provides a visual review of strategic leadership to help clarify the current research status and sort out the theoretical development; simultaneously, it summarizes and distills the current hot topics in strategic leadership research to provide direction and reference for the subsequent analysis in this field.

\section{Method}

The knowledge mapping approach in bibliometrics assumes that the subject matter changes over time, and its intrinsic logic follows the idea of paradigm evolution (Chen et al., 2015). The knowledge mapping approach allows a visual representation of the literature through a graph structure, with nodes representing authors, academic institutions, scientific literature, or keywords, and connecting lines representing the relationships between nodes, and has two significant bases: information visualization and co-word analysis. Information visualization refers to the graphical representation of data to discover information and guide decision making; the principle of co-word analysis is to form a co-word network by counting the frequency of a group of words in the same literature in two by two. The affinity relationship between the network nodes can reflect the structural changes of the research topic. Thus, we used HistCite and VOSviewer software for bibliometric analysis. HistCite can clearly show the interrelationship between literature in a research field with graphs, which can help analyze the development history and research lineage. VOSviewer is good at visualizing author networks, co-citation networks, coupling networks, and topic co-occurrence networks to help understand the distribution of research topics and reflect the hot spots of research in a particular field (Conz \& Magnani, 2020).

Therefore, we integrated the unique advantages of both software. Firstly, we used HistCite to locate the major academic journals and other information in the "Web of Science Core Collection" database and showed the vital literature and research lineage in this field. Secondly, we used VOSviewer software to analyze the core authors and institutions to illustrate the current status of cooperation in this field and analyzed the hot spots of strategic leadership research. Finally, based on the bibliometric work, the conclusions and prospects of this paper were further discussed.

\section{Data Sources}

This paper obtained data from the "Web of Science Core Collection" database, and the specific search steps are as follows. First, we used the Boolean searchable subject: ("strategic leader*") OR subject: ("top management" near/30 leadership) OR subject ("upper echelons" near/30 leadership) OR title: ("board of directors" near/30 leadership) OR title: (CEO near/30 leadership) in Web of Science's core database for subject (including title, abstract, or keywords) searches. Moreover, (1) We used an asterisk (*) as a wildcard to search for variants of terms such as strategic leadership (e.g., strategic leader). (2) When conducting searches in the top management, upper echelons, board of directors, and CEO fields, we also used the 
Boolean operator "near" to limit the spacing between the search terms and leadership to 30 words or less helps identify highly relevant documents. Second, we selected "Business" and "Management" subject categories in the "Research Areas" option. We streamlined the search results by selecting the subject categories of "Business" and "Management" for the "Research Areas" option and choosing Article, Review, and Early access for the Document Type. Finally, we manually reviewed the titles, keywords, abstracts, and individual references and full texts to determine whether they were included in the bibliometric scope based on their relevance to the topic of strategic leadership, resulting in a dataset of 416 documents with high relevance to strategic leadership during 1996-2021.

\section{An Overview of Strategic Leadership Research Growth Trend}

Figure 1 shows the cumulative publication data that were curve-fitted, and the $\mathrm{R}^{2}$ value of the goodness of fit is .95 , which reveals that the cumulative growth trend of strategic leadership literature conforms to the law of exponential growth. We divided the growth process into three stages: (1) 1996-2003, the primary growth trend is not apparent, and the research is in the exploration period, which is manifested by the small number of publications in each year, except for 2002, which is one publication per year. (2) from 2004 to 2015, the research was in the growth period. The publication volume reached a new level each year. The cumulative publication volume coincided with the fitted curve. The publication volume of related literature in 2011, 2012, and 2014 were more. (3) from 2016 to the present, the research was in a tumultuous period, showing rapid growth and flourishing trend, and the publication volume in 2016 was more than 2015 showed a trend of multiplication. Although the publication volume fell into a trough in 2018, the publication volume reached a new high in 2020. The research showed a new growth trend, thus showing that the future research of strategic leadership deserves attention.

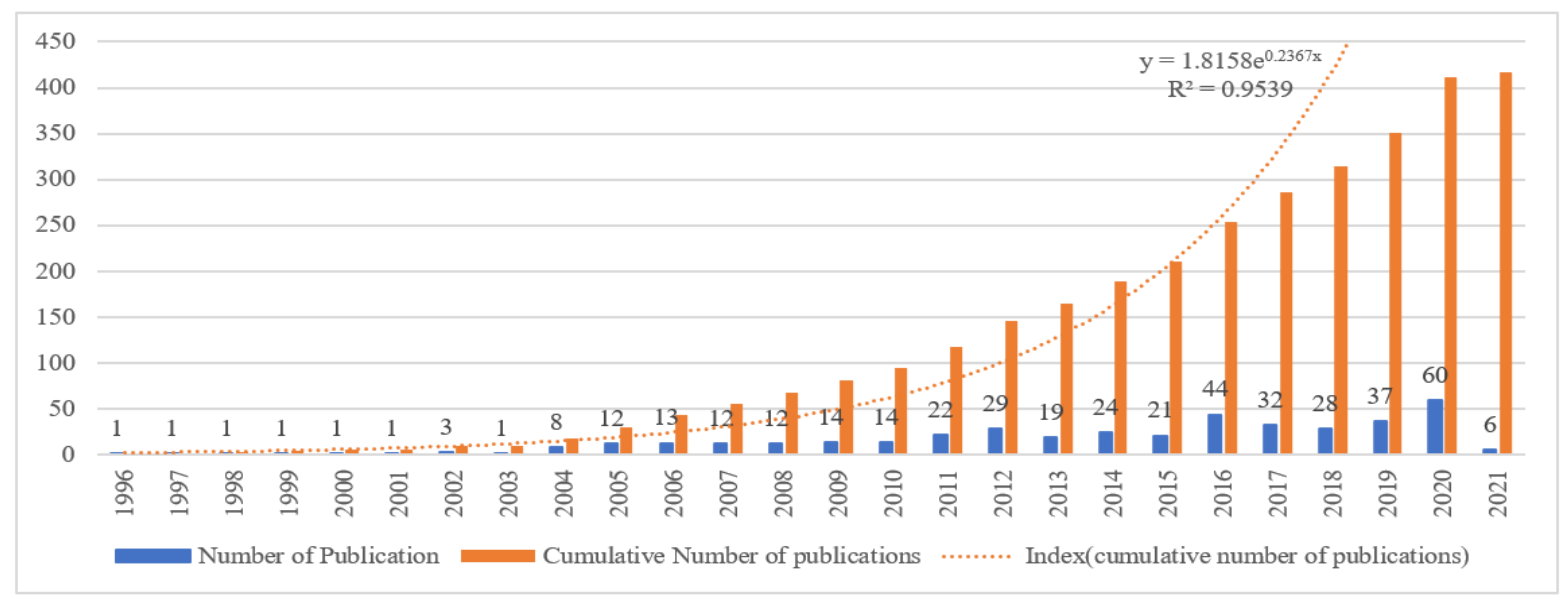

Figure 1. Time distribution of strategic leadership related research (1996-2021)

\section{Distribution of Journals}

We calculated the LCS (Local citation score, number of citations in this dataset), TLCS (Total local citation score), and TGCS (Total global citation score in the WOS). The higher the total local citation score, the higher the journal impact. This paper obtained 15 journals with 
TLCS $>7$ as the cut-off point. Table 1 shows their distribution. In terms of the number of publications on the topic of strategic leadership, Leadership Quarterly (30 papers), Journal of Business Ethics (26 papers), Strategic Management Journal (19 papers), Journal of Management (17 papers), Journal of Business Research (15 papers) and Journal of Management Studies (11 papers) are the leading six journals. Also, Leadership Quarterly, Academy of Management Journal, Academy of Management Review, and Journal of Management have a significant influence on strategic leadership research (their TLCS, TGCS values are high). Therefore, this paper argues that strategic leadership-related analysis will receive more attention as strategic leadership research grows. More relevant literature with high impact will appear in mainstream leadership and strategic management journals, which is an excellent opportunity for researchers.

Table 1

Journal Distribution of Strategic Leadership Research Literature

\begin{tabular}{|c|c|c|c|c|}
\hline \# & Journal & TLCS & TGCS & Number of Articles \\
\hline$\overline{1}$ & Leadership Quarterly & 184 & 2885 & 30 \\
\hline 2 & Academy of Management Journal & 70 & 880 & 7 \\
\hline 3 & Academy of Management Review & 63 & 882 & 4 \\
\hline 4 & Journal of Management & 62 & 1143 & 17 \\
\hline 5 & Strategic Management Journal & 59 & 984 & 19 \\
\hline 6 & Journal of Management Studies & 45 & 1025 & 11 \\
\hline 7 & Academy of Management Executive & 34 & 400 & 2 \\
\hline 8 & Journal of Business Ethics & 26 & 1352 & 26 \\
\hline 9 & Journal of Applied Psychology & 19 & 331 & 3 \\
\hline 10 & Personnel Psychology & 15 & 315 & 5 \\
\hline 11 & Organizational Behavior and Human Decision Processes & 11 & 717 & 1 \\
\hline 12 & Iee Transactions on Engineering Management & 8 & 110 & 2 \\
\hline 13 & Business Horizons & 7 & 62 & 4 \\
\hline 14 & Journal of Business Research & 7 & 193 & 15 \\
\hline 15 & Organization Science & 7 & 275 & 2 \\
\hline
\end{tabular}
global citation score per year. We only list journals with TLCS of 7 or above for the space limit.

\section{Core Authors, Research Institutions, and Important Literature}

\section{Analysis of Core Authors}

The core author refers to a few distinguished authors with a high number of publications, a high citation rate, and tremendous influence in a particular discipline or professional field, often guiding a specific research field. We classified authors with $\geq 3$ publications as core authors in strategic leadership. A total of 26 core authors were obtained, accounting for only $2.4 \%$ of all authors, which indicates that strategic leadership research has received attention from scholars in several fields. However, there are fewer core authors, and strategy is still in the growth stage.

We used Bibliographic Coupling analysis to show the research relationships among core authors. It could quickly reveal the substantive collaboration and shared interest points of research among different authors and help scholars analyze the hot issues in a field. Therefore, with the help of VOSviewer, a research relationship graph of 26 core authors was generated (see Figure 2). There are five clusters: (1) Red cluster: seven authors in this cluster. The core authors are Georgakakis and Ruigrok, professors at the Institute of International Management at the University of St. Gallen (Switzerland). Their research interests are strategy, management, international management, and they have close cooperation. (2) Green Cluster: there are five authors in this cluster, and the core author is Jansen, who is a professor in the Department of Strategic Management and Entrepreneurship at Erasmus University in Rotterdam, and whose primary research interests are leadership and organization design. Volberda, with whom he 
collaborates more closely, is a professor of strategy and innovation at the Universiteit van Amsterdam in the Netherlands. Vera is a professor of strategy in the Department of Management and Leadership at the University of Houston. Although the three authors come from different colleges, they have all made outstanding contributions to strategic management. (3) Blue cluster: there are four authors in this cluster, including Waldman, a professor of management and entrepreneurship at Arizona State University (USA), whose primary research interests include leadership, transformational leadership, and work performance, and who has published the most papers among the authors in the sample, and who is closely associated with professor Wang Hui from the Guanghua School of Management at Peking University. Hiller is the director of the Leadership Center at Florida International University and has a passion for senior leadership within organizations. Patel is a professor of strategy and innovation at Villanova University and has written several articles on organizational innovation, entrepreneurship, and women executives. (4) Yellow cluster: this cluster has three authors. Simsek Heavey is an associate professor of strategic management in the School of Business at the University of Connecticut (USA) and has edited several journals, including the Journal of Strategic Entrepreneurship, Management Research Journal, and several other journals focusing on strategic leadership and entrepreneurship. Simsek and Heavey are Teacher-Student relationships and have published together on several occasions. (5) Purple cluster: there are two authors in this cluster. The association between Carmeli and Tishler is the most obvious, indicating that they have a very close collaborative relationship. They have a high level of publications among the 23 core authors. They work together at the Tel Aviv University School of Management in Israel and have co-authored papers on strategic decision making, strategic leadership, and leadership on three occasions.

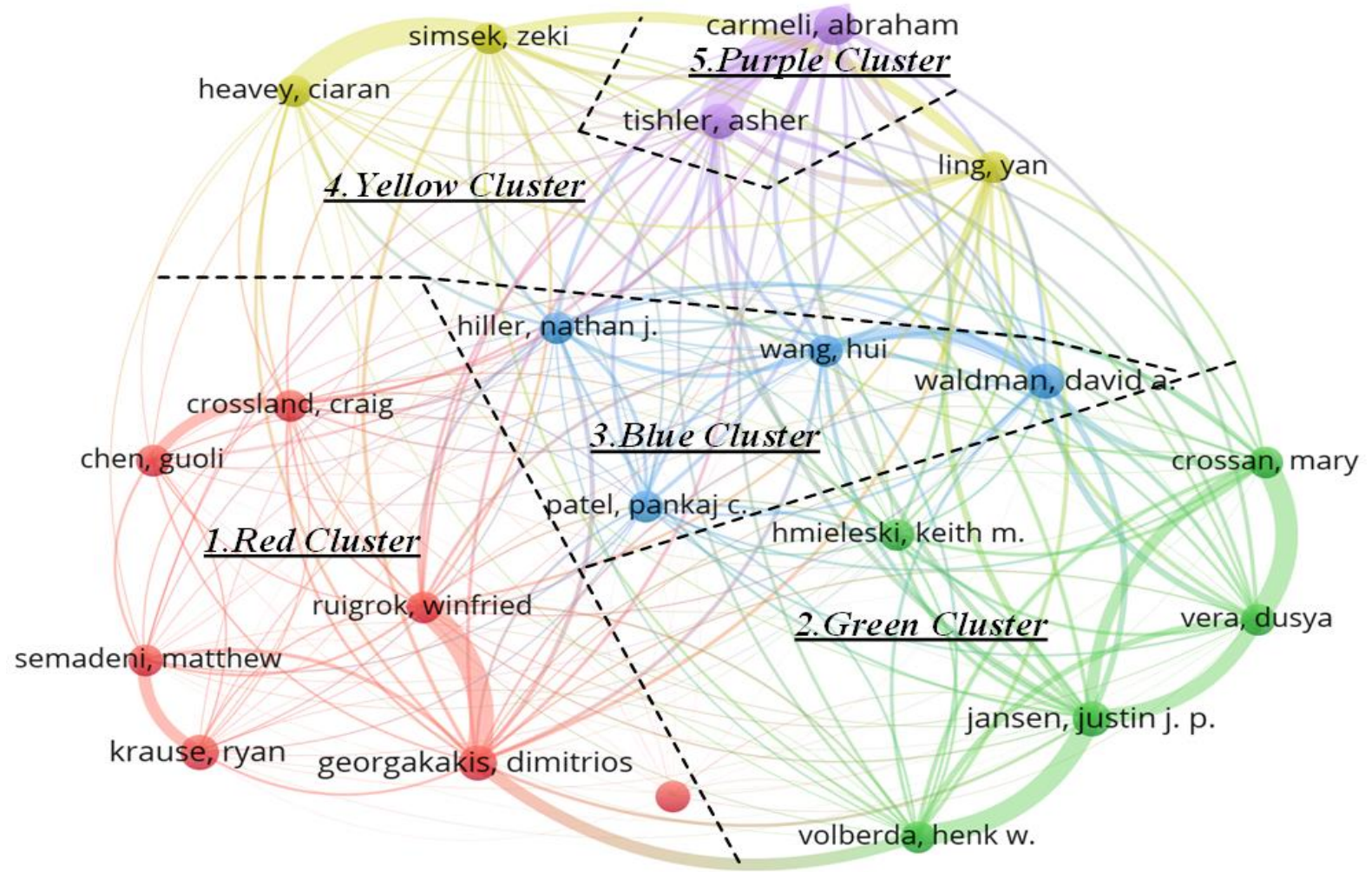

Figure 2. Core author research relationship map

Note. Each node denotes an author, node size denotes the number of author posts, color denotes the cluster to which the author belongs, and the width of the connecting line denotes the strength of the relationship between authors. 


\section{Core Research Institutions}

A core research institution analysis could reveal related institutions engaged in scientific research in a specific field on a long-term basis. Mining, statistical and visual analysis of related research institutions is a crucial activity in information collection, which helps us understand the current situation of research institutions in this field and clarify the cooperation among research institutions.

There are 567 research institutions in the sample of 416 papers. The institutions with $\geq 5$ articles are considered core research institutions. Only twenty-five institutions, accounting for $4.4 \%$ of the total, are eligible, which shows that the research institutions in strategic leadership are concentrated. The related research needs to be further expanded and deepened. Similar to the analysis of core authors, this paper presents the relationship among core research institutions through Bibliographic Coupling analysis with the help of VOSviewer. Figure 3 indicates that the research in strategic leadership is not confined to one institution but has a global scope of cross-institutional and cross-regional cooperation. There are also more collaborative studies between domestic and foreign institutions, thus forming a tight and complex collaborative network.

In terms of partnerships, these 25 institutions form into four clusters: (1) Red cluster: there are nine research institutions in this cluster, among which Arizona State University (USA) has the highest number of publications and collaborates with many institutions, as well as with the Chinese government, universities and research institutions, indicating that it is an important location for research in the field of strategic leadership. The University of St. Gallen, where Arizona State University collaborates more frequently, is dedicated to training business and public administration people. Texas A\&M University has strong research capabilities and extensive collaborative experience, which enrich the current research in strategic direction leadership. (2) Green Cluster: there are six institutions in this cluster, among which Hong Kong Baptist University, the oldest higher education institution in Hong Kong, has traditionally placed great emphasis on international cooperation and cultural exchange and has maintained close cooperation with the other five institutions. (3) Blue Cluster: there are five institutions in this cluster. Four institutions, Baylor University (USA), Rutgers State University (USA), Monash University (Australia), Deakin University (Australia), led by Texas Christian University (USA), have together made significant contributions to the field of strategic leadership. (4) Yellow Cluster: there are four institutions in this cluster. Erasmus University in Rotterdam and the University of Houston in the USA have the leading position in strategic leadership studies. 


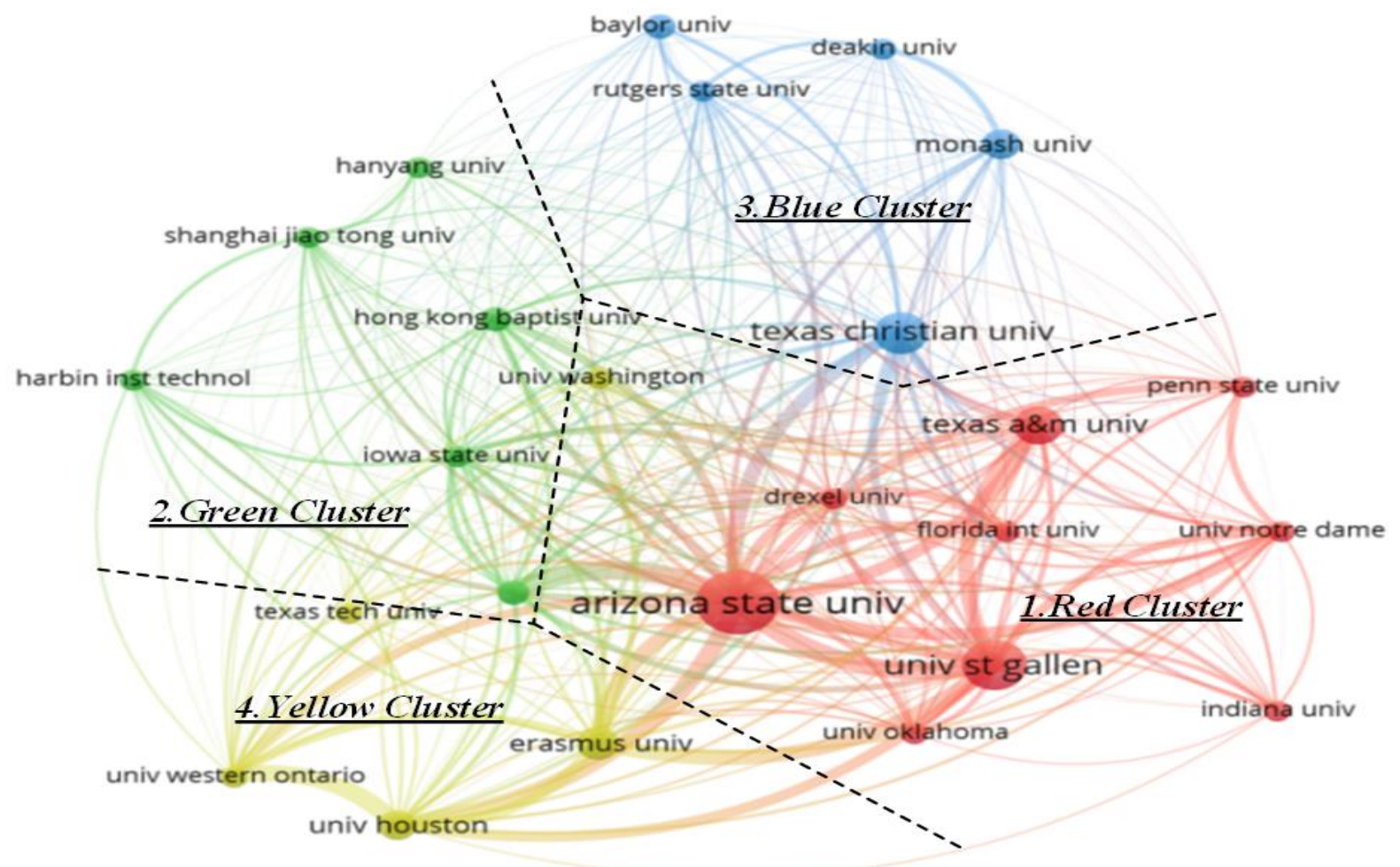

Figure 3. Core institutional research relationship map

Note. Each node denotes an institution, node size denotes the volume of institutional postings, color denotes the cluster to which the institution belongs, and the width of the connecting line denotes the strength of the relationship between institutions.

\section{Analysis of Important Literature}

HistCite can detect important literature in the field with the help of three indicators, LCS, LCS/t, and LCS (e/b): (1) LCS refers to the cited number of literature in the local database. The higher the LCS value, the more influential the literature is, and the more critical the literature is in the research field. In this paper, we extracted 20 important papers with LCS $\geq 11$ (see

Table 2), among which, the first four papers 26\#Vera and Crossan (2004), 75\#Ling et al. (2008), 44\#Ireland and Hitt (2005), 28\#Waldman et al. (2004) are essential source papers in this field. (2) LCS/t value means LCS value/(difference between the year of data acquisition and year of paper publication), which considers the time of publication. Furthermore, a high $\mathrm{LCS} / \mathrm{t}$ value indicates that the literature has a long-term influence, e.g., the LCS/t values of literature 26\# Vera and Crossan (2004) and 75\# Ling et al. (2008) in

Table 2 are much larger than those of other literature. (3) LCS (e/b) value represents the ratio of citation of in the recent local dataset to the citations of in the period when the paper was first published, if LCS $(\mathrm{e} / \mathrm{b})>1$, it means that the paper has been cited more often in the recent period than in the period when it was first published. The literature with LCS $(\mathrm{e} / \mathrm{b})$ values $\geq 4$ in

Table 2 includes 86\# Jansen et al. (2009), 94\# Resick et al. (2009), 82\# Yukl (2008), and 87\# Nemanich and Vera (2009), which indicates that these literature has received more scholarly attention in the recent past. 
Table 2

Important Literature on Strategic Leadership and its Impact

\begin{tabular}{|c|c|c|c|c|c|c|}
\hline \# & Literature Title & Author & Journal & LCS & $\begin{array}{c}\mathrm{LCS} \\
/ \mathrm{t}\end{array}$ & $\begin{array}{l}\text { LCS } \\
(\mathrm{e} / \mathrm{b})\end{array}$ \\
\hline 26 & Strategic leadership and organizational learning & Vera \& Crossan (2004) & AMR & 45 & 2.5 & $11 / 0$ \\
\hline 75 & $\begin{array}{l}\text { Transformational leadership's role in Promoting Corporate } \\
\text { Entrepreneurship: Examining the CEO-TMT Interface }\end{array}$ & Ling et al. (2008) & AMJ & 32 & 2.29 & 1.33 \\
\hline 44 & $\begin{array}{l}\text { Achieving and maintaining strategic competitiveness in the } \\
21 \text { (st) century: The role of strategic leadership }\end{array}$ & Ireland \& Hitt (2005) & AME & 30 & 1.76 & 0.5 \\
\hline 28 & $\begin{array}{l}\text { Charismatic leadership at the strategic level: A new } \\
\text { application of upper echelons theory }\end{array}$ & Waldman et al. (2004) & LQ & 25 & 1.39 & 2.00 \\
\hline 48 & $\begin{array}{l}\text { Does CEO Charisma Matter? An Empirical Analysis of the } \\
\text { Relationships among Organizational Performance, } \\
\text { Environmental Uncertainty, and Top Management Team } \\
\text { Perceptions of CEO Charisma }\end{array}$ & Agle et al. (2006) & AMJ & 22 & 1.38 & 1.00 \\
\hline 86 & $\begin{array}{l}\text { Strategic leadership for exploration and exploitation: The } \\
\text { moderating role of environmental dynamism }\end{array}$ & Jansen et al. (2009) & LQ & 22 & 1.69 & 4.00 \\
\hline 43 & $\begin{array}{l}\text { Straegic leadership and executive innovation influence: An } \\
\text { international multi-cluster comparative study }\end{array}$ & Elenkov et al. (2005) & SMJ & 21 & 1.24 & 1.5 \\
\hline 122 & $\begin{array}{l}\text { How CEO empowering leadership shapes top management } \\
\text { team processes: Implications for firm performance }\end{array}$ & Carmeli et al. (2011) & LQ & 19 & 1.73 & 1.33 \\
\hline 42 & $\begin{array}{l}\text { Executive job demands: New insights for explaining } \\
\text { strategic decisions and leader behaviors }\end{array}$ & Hambrick et al. (2005) & AMR & 17 & 1.00 & $5 / 0$ \\
\hline 94 & $\begin{array}{l}\text { The Bright-Side and the Dark-Side of CEO Personality: } \\
\text { Examining Core Self-Evaluations, Narcissism, } \\
\text { Transformational Leadership, and Strategic Influence }\end{array}$ & Resick et al. (2009) & JAP & 15 & 1.15 & 5.00 \\
\hline 82 & How leaders influence organizational effectiveness & Yukl (2008) & LQ & 13 & 0.93 & 4.00 \\
\hline 141 & $\begin{array}{l}\text { Functional Top Management Team Members: A Review, } \\
\text { Synthesis, and Research Agenda }\end{array}$ & Menz (2012) & JM & 13 & 1.3 & 0.67 \\
\hline 41 & $\begin{array}{l}\text { Top management leadership and influence on innovation: } \\
\text { The role of sociocultural context }\end{array}$ & Elenkov \& Manev (2005) & $\mathrm{JM}$ & 12 & 0.71 & 3.00 \\
\hline 58 & $\begin{array}{l}\text { Components of CEO transformational leadership and } \\
\text { corporate social responsibility }\end{array}$ & Waldman et al. (2006) & JMS & 12 & 0.75 & $1 / 0$ \\
\hline 72 & $\begin{array}{l}\text { CEO transformational leadership: The role of goal } \\
\text { importance congruence in top management teams }\end{array}$ & Colbert et al. (2008) & AMJ & 12 & 0.86 & 2.00 \\
\hline 84 & $\begin{array}{l}\text { How low does ethical leadership flow? Test of a trickle- } \\
\text { down model }\end{array}$ & Mayer et al. (2009) & OBHP & 11 & 0.85 & $0 / 4$ \\
\hline 87 & $\begin{array}{l}\text { Transformational leadership and ambidexterity in the } \\
\text { context of an acquisition }\end{array}$ & Nemanich \& Vera (2009) & LQ & 11 & 0.85 & 5.00 \\
\hline 118 & $\begin{array}{l}\text { CEO leadership behaviors, organizational performance, and } \\
\text { employees' attitudes }\end{array}$ & Wang et al. (2011) & LQ & 11 & 1.00 & 2.00 \\
\hline 38 & $\begin{array}{l}\text { CEO transformational leadership and organizational } \\
\text { outcomes: The mediating role of human-capital-enhancing } \\
\text { human resource management }\end{array}$ & Zhu et al. (2005) & LQ & 10 & 0.59 & 3.00 \\
\hline 53 & $\begin{array}{l}\text { The importance of vertical and shared leadership within } \\
\text { new venture top management teams: Implications for the } \\
\text { performance of startups }\end{array}$ & Ensley et al. (2006) & LQ & 10 & 0.63 & $1 / 0$ \\
\hline
\end{tabular}

Note. \# denotes the marker number within the set of documents searched for in this paper; black underline in the table denotes important documents; journal abbreviations are as follows: AMR=Academy of Management Review, AMJ=Academy of Management Journal, $\mathrm{AME}=$ Academy of Management Executive, LQ=Leadership Quarterly, SMJ=Strategic Management Journal, JAP=Journal of Applied Psychology, JM=Journal of Management, JMS=Journal of Management Studies.

\section{Strategic Leadership Connotation, Research Streams, and Hot Topics Strategic Leadership Connotation}

By reading and analyzing the sample literature, we found that the scope of research in strategic leadership was gradually broadening. The depth of research was deepening, and there was still 
a lack of consensus in the academic community on the concept and interpretation perspective of strategic leadership. The definition of strategic leadership was still fragmented and lacking consensus, providing scholars with future research opportunities.

Hosmer (1982) first introduced the concept of strategic leadership as establishing an overall sense of purpose and direction in an organization to guide and integrate the development and implementation of corporate strategy. This definition clearly defines the difference between manager and leader, who needs to consider the interaction between the organization and the external macroenvironment. Elenkov and Manev (2005) define strategic leadership as future vision building, talking to subordinates, stimulating and motivating followers, and providing peer and subordinate support for strategic change, which is closer to the characteristics of transformational leaders proposed by subsequent studies. Cortes and Herrmann (2021) consider strategic leadership a widely used term and define it as the eight functions performed by individuals at the top of the organization (CEO, TMT members, directors, general managers) to have a strategic impact on the company.

Most of the existing studies define the connotation of strategic leadership from three perspectives: the competence perspective views strategic leadership as a special competence possessed by top leaders (Glenn, 2001; Martin et al., 1996). The process perspective views it as a unique process (Hosmer, 1982; House \& Aditya, 1997), including increasing organizational competitiveness, maintaining organizational stability, and achieving strategic goals. The style perspective views strategic leadership as a leadership style, and most scholars classified strategic leadership as transactional and transformational leadership (Azbari et al., 2015; Vera \& Crossan, 2004). Although these three perspectives have greatly enhanced the comprehension of strategic leadership, there is a problem of insufficient cooperation and disagreement among researchers. As a lack of consensus in the academic community, strategic leadership is still fragmented and challenging to form a precise definition. Therefore, theoretical clarification in this area of strategic leadership is essential.

\section{Research Streams Description}

The chronological citation map of HistCite can visualize the communication dynamics of vertical succession and horizontal connection among the critical literature in this field. This paper generated 42 papers from the 416 sample documents using LCS $\geq 5$ as the criterion (see Figure 4). 


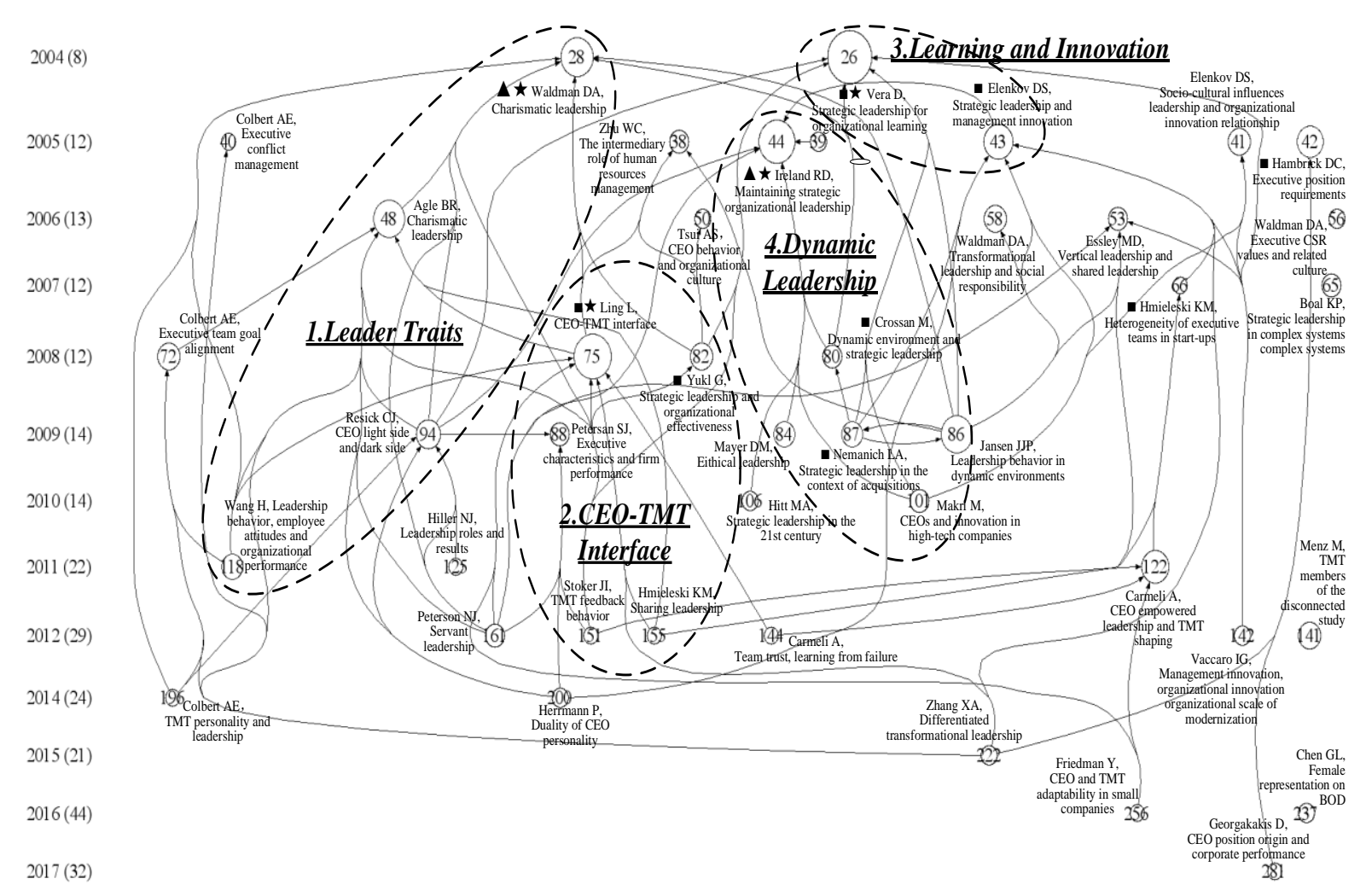

Figure 4. Chronological citation graph of strategic leadership based on HistCite

Note. Each circle represents a vital paper, the circle size represents the amount of literature cited, the arrow between the circles indicates the citation relationship between the literature, the arrow points to the cited literature, and the end of the arrow points to the cited literature. The paper marked with $\star$ represents the source literature in the field, the marked with $\mathbf{r}$ represents the recently published literature review. The paper marked with $\boldsymbol{\Delta}$ represents it has recently increased attention in the field. Also, we can analyze the latest research in the field according to the density of the line. If the line is very dense, the latest research is active.

The 42 highly cited papers range from 2004 to 2017, with 2012 noteworthy. Since 2012, strategic leadership-related research has gradually shifted from individual CEO and executive studies to executive team and collaborative interaction studies, indicating that the overall research trend of strategic leadership began to shift from the individual level to the team level and organizational level. The four source papers started the strategic leadership research boom from the perspectives of individual characteristics of strategic leaders (Waldman et al., 2004), CEO-TMT interface (Ling et al., 2008), organizational learning (Vera \& Crossan, 2004), and dynamic environment (Ireland \& Hitt, 2005) perspectives, which started the research boom on strategic leadership and from which four research lines have been derived (see Figure 4): first, the leader traits research with Waldman and Resick as the core authors; second, the CEO-TMT interface research with Ling as the core authors; third, the learning and innovation research with Vera and Ireland as the core authors; fourth, the dynamic leadership research with Crossan and Nemanich as the core authors. 
Table 3

Four Source Documents for Strategic Leadership Research

\begin{tabular}{|c|c|c|c|}
\hline \# & Author/Journal & Strategic leadership building points & Reviews \\
\hline 26 & $\begin{array}{l}\text { Vera \& \& } \\
(2004) / A M R\end{array}$ & $\begin{array}{l}\text { - Organizational learning is the process of change in thinking and action, of } \\
\text { sharing knowledge between individuals and organizational bodies. } \\
\text { Organizational learning is a fundamental strategic process and the primary } \\
\text { means of strategic renewal. } \\
\text { - An ideal strategic leader should identify the right time to learn, recognize } \\
\text { when feed-forward or feedback learning is needed, and which leadership style } \\
\text { is appropriate to achieve that goal. }\end{array}$ & $\begin{array}{l}\text { Focus on organizational } \\
\text { leadership and the } \\
\text { importance of strategic } \\
\text { leadership for } \\
\text { organizational learning } \\
\text { mechanisms }\end{array}$ \\
\hline 28 & $\begin{array}{l}\text { Waldman et } \\
(2004) / L Q\end{array}$ & $\begin{array}{l}\text { - Charismatic leadership at the strategic level: new applications of senior } \\
\text { leadership theory. } \\
\text { - Strategic leaders use charismatic leadership, and charismatic relationships } \\
\text { with followers help ensure the implementation of strategic decisions initiated } \\
\text { by executives. }\end{array}$ & $\begin{array}{l}\text { - The importance of } \\
\text { leadership style and } \\
\text { personal traits of } \\
\text { strategic leaders }\end{array}$ \\
\hline 44 & $\begin{array}{l}\text { Ireland \& } \\
(2005) / A M E\end{array}$ & $\begin{array}{l}\text { - In the } 21 \text { st-century global economy, competition is complex, challenging, and } \\
\text { full of competitive opportunities and threats. Effective strategic leadership } \\
\text { practices can help companies improve performance while competing in a } \\
\text { volatile and unpredictable environment. } \\
\text { - Effective strategic leadership includes determining the company's goals and } \\
\text { vision, developing and maintaining core competencies, developing human } \\
\text { capital, maintaining an influential organizational culture, emphasizing ethical } \\
\text { practices, and establishing balanced organizational control. }\end{array}$ & $\begin{array}{l}\text { - Dynamic environmental } \\
\text { impact strategy } \\
\text { leadership }\end{array}$ \\
\hline 75 & Ling et al. (2008)/AMJ & $\begin{array}{l}\text { - Transformational leadership entails transforming individuals, teams, and } \\
\text { companies by going beyond the status quo to impact the company's ability to } \\
\text { innovate and adapt. } \\
\text { - Transformational CEOs can influence corporate entrepreneurship by } \\
\text { encouraging their TMTs to respond better to new opportunities and associated } \\
\text { risks and becoming more committed to launching and supporting } \\
\text { entrepreneurial initiatives. }\end{array}$ & $\begin{array}{l}\text { - Focus on the interaction } \\
\text { and impact of strategic } \\
\text { leaders with TMT and } \\
\text { the led }\end{array}$ \\
\hline
\end{tabular}

\section{(1) Leader Traits}

This stream of research originated from the source literature of 28\# Waldman et al. (2004), which mainly emphasized the importance of individual traits of strategic leaders, including traits such as cognition, experience, ethics, knowledge, gender, personality, and leadership style of strategic leaders. Due to the ease and availability of data search, strategic leader traits have become a virtual research object in this field. The Upper Echelon theory revealed the leader's profound influence (Finkelstein et al., 1996). Resick et al. (2009) argue that CEO personality traits influence the strategy, structure, and performance of the organizations they lead. CEOs with bright personality traits are more likely to be strategic leaders. Wang et al. (2011) developed a six-dimensional measure of CEO leadership behavior from leadership behavior and showed that CEO relationship-centered behavior could impact employee attitudes and firm performance. Since the Upper Echelon theory dominated initial strategic leadership research, leader traits have been steadily high and continue today.

\section{(2) CEO-TMT Interface}

The second vein is the CEO-TMT Interface, closely related to 75\# Ling et al. (2008). It focuses on the importance of strategic leaders, interacting and cooperating, sharing leadership, and creating team trust between CEOs and TMTs. As the volatility and complexity of the organization's internal and external environments continue to deepen, there is an urgent need for the organization to expand the team of strategic leaders, shift from individual CEO decisionmaking to collective TMT decision-making. Overcome the obstacles and constraints in the decision-making shift process, and move toward convergence in the friction process, ultimately 
forming a strategic leadership system with a unified organizational consciousness and vision (Ma \& Seidl, 2018), thereby enabling the organization to better cope with risk challenges. Therefore, the vein of the CEO-TMT Interface can be said to originate from the requirements of the external dynamic environment of competitive changes. Stoker et al. (2012) suggest that the effectiveness of CEO transformational leadership depends on the feedback-seeking behavior of the top management team (TMT). Ensley et al. (2006) use event theory as a framework to demonstrate that shared authentic leadership is the most crucial factor in the organization's development. Zhang et al. (2015) also proposed a management perspective of "getting everyone on board" to allow TMTs to make strategic decisions with the CEO. Therefore, to ensure the effectiveness of strategic leadership in an organization, it is not enough to have interaction and cooperation at the CEO-TMT level but also to raise the strategic awareness of other people in the organization (Crossan et al., 2008).

\section{(3) Learning and Innovation}

The third research vein is learning and innovation, closely related to the source literature 26\# Vera and Crossan (2004). Learning and innovation are two indispensable aspects of sustaining and improving organizational competitiveness. They are also one of the key elements for the success of strategic leadership. In essence, learning and innovation embody strategic leadership behaviors in an organization. An ideal strategic leader should identify the right time for learning and recognize when feed-forward or feedback learning is needed (Vera \& Crossan, 2004). Elenkov and Manev (2005) found that strategic leadership behavior has a strong positive relationship with product market and executive innovation, while the heterogeneity of TMT tenure moderates the relationship. The existing literature in this line of research focuses on "long-term," "continuity," and "high impact" indicators such as organizational learning and organizational innovation, which are also highly relevant in the area of strategic leadership behavior outcomes. The study of these indicators helps to clarify the relationship between strategic leadership behavior and its results and meets the goal of strategic leadership to focus on "long-term organizational development."

\section{(4) Dynamic Leadership}

The source literature in this research vein, 44\# Ireland and Hitt (2005), states that competitive relationships in the global economy of the 21 st century are complex and dynamic. Managers must develop and use dynamic leadership skills and handle the alignment of three related domains: environment, strategy, and organization, to be transcendent strategic leaders in a challenging and competitive environment (Crossan et al., 2008). How organizations can adequately analyze the dynamic environment and seize the opportunities to face the challenges is a question worthy of consideration and a new requirement and challenge for strategic leaders. Effective strategic leadership practices can help companies gain a competitive advantage in turbulent and unpredictable environments and improve organizational performance (Bergh et al., 2016). Nemanich and Vera (2009) explored transformational leadership in the context of acquisitions. At the same time, Jansen et al. (2009) revealed how leadership behaviors affected innovation outcomes and explained how the dynamic influence of environmental conditions on leadership behavior. When engaging in strategic choices and decisions, contemporary strategic leaders need to consider the actual situation of their organizations and have a variety of leadership skills such as analyzing the dynamic global context, thinking differently, and 
innovating. With the advent of the digital era and the information technology explosion, strategic leaders face new pressures and challenges in their management practices. In this context, how do leaders innovate in real-time for strategic leadership? How to lead enterprises to resolve crises and risks? It is to be further deepened and explored.

\section{Hot Topic Exploration}

In the sample literature set selected for this study, there are 331 papers from the last decade, accounting for $81 \%$ of the total literature set. Based on the distribution of literature, most of the literature with high attention (high citation) is also in the last decade. Therefore, this paper uses the Co-occurrence function of the natural language processing and visualization tool VOSviewer to show the hot topics in strategic leadership. Specifically, the "abstract" in the literature is used as the object of analysis in this paper. The "all-in" approach is adopted, with the word frequency set to 15 and the relevance threshold set to $60 \%$. First, a total of 158 keywords are extracted. Secondly, from the initial screening of keywords, the words related to research methods such as "review, question, survey, paper" were deleted. Figure 5 shows words map with 67 keywords obtained, in which we can identify five hot research areas: strategic leaders, corporate governance, ethical practices, organizational learning, and organizational change and innovation.

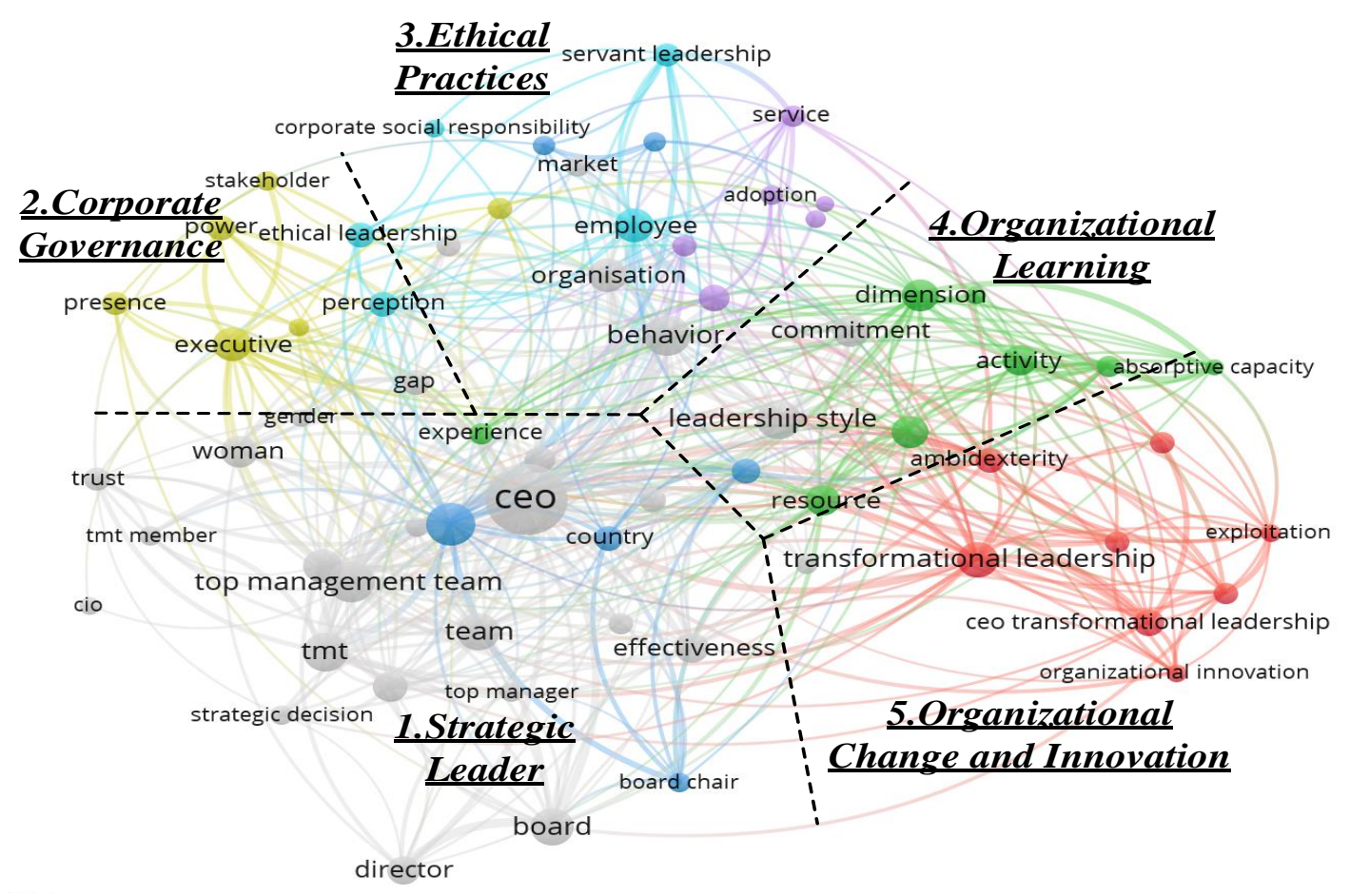

Figure 5. Map of research subject words convergence of strategic leadership based on VOSviewer

\section{(1) Strategic Leaders}

Strategic leaders have been a hot issue in strategic leadership research. For firms, CEOs have high status and power. Their leadership, decision-making, and execution capabilities can significantly impact the firm, so the early strategic leadership studies mainly focused on CEOs. At the same time, there was a lack of attention to other top managers who have the primary strategic decision-making responsibilities. Scholars went beyond the individual study with the 
CEO as the primary target under the dual challenges of the organization's external environment and internal structure. They started to focus on collaborative communication between other leaders, especially the TMT and the CEO. Crossan et al. (2008) argued that excellence in leadership focuses on three levels of leadership: self-leadership, the leadership of others, and organizational leadership, and gives suggestions to consider the executive team leader rather than limiting to individual leadership. Ling et al. (2008) also state that transformational CEOs can influence corporate entrepreneurship by encouraging the TMT to address risks and challenges better and initiating and supporting entrepreneurial initiatives. Thus, the CEO and TMT relationship is never fragmented, and effective strategic leadership needs to consider the relationship between top management and all parties (Simsek et al., 2018). Future research can further explore the interaction between CEO and TMT, for example: to what extent does the transformational CEO influence the changed behavior of other TMT members? How does the CEO shape the characteristics of other TMT members and thus influence strategic decisions?

\section{(2) Corporate Governance}

There have been different definitions of corporate governance in academic circles. The widely accepted definition is that corporate governance involves governance structure and mechanism. Its goal is to achieve scientific, corporate decision-making rather than mutual checks and balances. According to Qian (1995), the corporate governance structure is a set of institutional arrangements that govern the relationships between several groups with significant interests in the company and realize economic benefits from them, emphasizing the interests and checks and balances among the stakeholders within the firm. The study of corporate governance can effectively improve the operational efficiency and organizational performance of modern companies and help enhance the strategic performance of organizations (Zheng, 2004). As essential stakeholders in corporate governance, the board of directors, general manager, and shareholders handle the relationship sufficiently, effectively promoting strategic leaders' decisions and implementation and maximizing the strategic utility. In the era of network and ecology, organizations can never live as an island. They are in various transactional, alliance, political, and emotional relationships. The shift from focusing on shareholders to stakeholders is a potential trend in corporate governance and strategic leadership research (Trahms et al., 2013). Therefore, it is also worthy of further in-depth research on how strategic leaders can precisely position their governance objectives, promote the optimization of governance structures, coordinate internal and external governance mechanisms, and enhance the efficiency of corporate governance.

\section{(3) Ethical Practices}

With the increasing public demands on companies, the ethical practice behavior of business leaders has become a hot spot in recent years (Brown \& Mitchell, 2010). Ethical practice mainly refers to communicating the required normative behavior to employees through individual behavior and interpersonal interactions, prompting employees to follow directions through democratic leadership such as two-way communication (Brown et al., 2005). This hotspot is mainly based on ethical standards, emphasizing care for the interests of employees and society (Ladkin, 2008), and requires leaders not to use coercive or unethical means to force employees to comply with leadership but to move toward democratic, charismatic, servant, and ethical leaders. For instance, ethical leaders should focus on the interests of others (Brown et 
al., 2005) and be consistent in their words and actions based on ethical standards. At the same time, ethical leaders are good at attracting and regulating employees by using personal charisma and ethically acceptable organizational standards to create a more open-minded environment. Through the dual combination of material interests and spiritual needs between the enterprise and the employees, the open-mindedness of the employees brings more space for development. The realization of the organization's strategic goals requires the long-term consideration and precise choice of strategic leaders and the cooperation and action of all stakeholders. Therefore, how strategic leaders can respond to the internal and external changes of the organization and carry out ethical practices will be an issue to be further investigated in the field of strategic leadership in the future.

\section{(4) Organizational Learning}

Organizational learning usually includes exploring new knowledge and integrating old and new knowledge, including exploratory and utilization learning (Politis, 2005). An excellent strategic leader should promptly identify dynamic external environmental changes, create intraorganizational learning opportunities, select appropriate learning approaches, and transform organizational learning into a team-wide and organization-wide activity (Vera \& Crossan, 2004). Organizational learning enables companies to create good business performance by improving new product development and market share. It also enables companies to continuously create and acquire new knowledge, build unique organizational competitive advantages, and enhance capabilities (Huber, 1991). Meanwhile, organizations with intense learning and absorption capacity tend to be resilient, so studying strategic leadership is extremely valuable for enhancing organizational resilience. However, in strategic leadership, researchers have seldom explicitly addressed the role of strategic leaders, i.e., CEOs and TMTs, in implementing organizational learning in companies and have not carefully studied and explained the mechanisms and specific behaviors of strategic leaders in influencing organizational learning. Therefore, future research could also delve into the mechanisms underlying organizational learning to promptly help strategic leaders update their organizational strategies, structures, and organizational cultures that have far-reaching effects on their organizations.

\section{(5) Organizational Change and Innovation}

Organizational change refers to a series of activities triggered by internal and external factors to better adapt to the environment and thus improve its competitiveness and organizational performance (Barnett \& Carroll, 1995). On the one hand, changes in the external environment make the current organization unable to adapt to the environmental requirements and must make changes and innovations. On the other hand, the obsolescence, rigidity, and inefficiency of the internal factors require the organization to make corresponding changes to achieve the organization's survival and development (Hannan \& Freeman, 1984). Meanwhile, organizational innovation is the whole process by which an organization integrates internal and external resources to realize ideas, products, services, processes that are new and useful (Daft, 1978; Oke et al., 2009). Any organization must continuously change and innovate in response to changes in the external environment and internal conditions to grow, thrive, and avoid aging and death. Thus, strategic leadership pays much attention to corporate change and innovation. For example, Frambach and Schillewaert (2002) found that firms are more likely to engage in 
innovative activities in competitive markets, and Elenkov and Manev (2005) found that strategic leadership behavior has a strong positive effect on product market and administrative innovation. Therefore, strategic leaders must pay attention to organizational change and innovation.

\section{Research Conclusions and Future Prospects}

As a critical element for organizations to enhance competitiveness and maintain competitive advantage, the study of strategic leadership has important theoretical and practical implications for both academic and practical communities. This paper provides a comprehensive review and analysis of existing strategic leadership research based on 416 highly relevant literature on strategic leadership, using two bibliometric tools, HistCite and VOSviewer. First, this paper describes an overview of strategic leadership research, including growth trends, journal distribution, core authors, research institutions, and vital literature. Second, this paper depicts four research streams in existing research: leader traits, CEO-TMT interface, learning and innovation, and dynamic leadership. Third, this paper extracts five hot directions and subject terms of research value: strategic leaders, corporate governance, ethical practices, organizational learning, and organizational change and innovation through keyword analysis. Effective strategic leadership can help organizations maintain their core competencies and positively impact many aspects of organizational systems, culture, innovation, and change, making it highly valuable for research. Although the current research results in this field are fruitful, some areas still deserve deeper investigation, and this paper also provides several potential directions:

First, related empirical studies to strategic leadership mostly use the method of leadership scale for measurement and analysis (Aarons et al., 2014; Elenkov \& Manev, 2005). Future research should develop scientific and reliable measurement systems and indicators to address the above problems by combining the new connotations of strategic leadership (Dalton \& Aguinis, 2013). As the environment changes, the connotation of strategic leadership will be constantly updated, and scholars need to grasp its connotation dynamically and update the existing measurement system or develop new measurement indicators.

Second, the current digital transformation supported by "ABCD” (Artificial Intelligence, Blockchain, Cloud Computing, Big Data) has a disruptive impact on organizational strategy and development issues (Caputo et al., 2021). Digital technology has put forward new requirements and challenges for strategic leadership. The organization should be proficient in the ability to make quick decisions, manage disruptive change, master digital technologies, and develop leadership skills to meet the digital challenges and make strategic leadership in the information age be more effective.

Third, most of the research on strategic leadership before 2012 focused on individual CEOs. Recent research proposes that organizational success depends not on the CEO alone but the senior and middle managers (Luciano et al., 2020). Only when members of the organization consciously join the strategic leadership team, understand the strategic decisions made by senior leaders and actively cooperate in their implementation can the organization's strategic leadership achieve maximum effectiveness. Therefore, future research can promote strategic leadership systems and provide more explicit strategic guidance for the organization. 
Finally, there are some limitations to this study. The limitation of search statements may result in some omissions or biases. Also, considering the clarity of the graphs, this paper sets the specific extraction threshold of keywords in the data analysis, which may impact reflecting the complete picture of strategic leadership research.

\section{References}

Aarons, G. A., Ehrhart, M. G., \& Farahnak, L. R. (2014, Apr 14). The implementation leadership scale (ILS): Development of a brief measure of unit level implementation leadership. Implementation Science, 9, Article 45. https://doi.org/10.1186/1748-5908-9-45

Agle, B. R., Nagarajan, N. J., Sonnenfeld, J. A., \& Srinivasan, D. (2006). Does CEO charisma matter? An empirical analysis of the relationships among organizational performance, environmental uncertainty, and top management team perceptions of CEO charisma The Academy of Management Journal, 49(1).

Azbari, M. E., Akbari, M., \& Chaijani, M. H. (2015). The effect of strategic leadership and empowerment on job satisfaction of the employees of Guilan University. International Journal of Organizational Leadership, 4(4).

Barnett, W. P., \& Carroll, G. R. (1995). Modeling Internal Organizational Change. Annual Review of Sociology, 21, $217-$ 236. https://doi.org/10.1146/annurev.so.21.080195.001245

Bergh, D. D., Aguinis, H., Heavey, C., Ketchen, D. J., Boyd, B. K., Su, P. R., Lau, C. L. L., \& Joo, H. (2016, Mar). Using meta-analytic structural equation modeling to advance strategic management research: Guidelines and an empirical illustration via the strategic leadership-performance relationship [Article]. Strategic Management Journal, 37(3), 477497. https://doi.org/10.1002/smj.2338

Brown, M. E., \& Mitchell, M. S. (2010, Oct). Ethical and unethical leadership: exploring new avenues for future research. Business Ethics Quarterly, 20(4), 583-616. https://doi.org/10.5840/beq201020439

Brown, M. E., Trevino, L. K., \& Harrison, D. A. (2005, Jul). Ethical leadership: A social learning perspective for construct development and testing. Organizational Behavior and Human Decision Processes, 97(2), 117-134. https://doi.org/10.1016/j.obhdp.2005.03.002

Caputo, A., Pizzi, S., Pellegrini, M. M., \& Dabić, M. (2021). Digitalization and business models: Where are we going? A science map of the field. Journal of Business Research, 123, 489-501. https://doi.org/10.1016/j.jbusres.2020.09.053

Carmeli, A., Schaubroeck, J., \& Tishler, A. (2011, Apr). How CEO empowering leadership shapes top management team processes: Implications for firm performance. Leadership Quarterly, 22(2), $399-411$. https://doi.org/10.1016/j.leaqua.2011.02.013

Chen, Y., Chen, C., Liu, Z., Hu, Z., \& Wang, X. (2015). Methodological functions of CiteSpace Knowledge Graph. Studies in Science of Science. http://lib.cqvip.com/Qikan/Article/Detail?id=1005692500

Colbert, A. E., Kristof-Broiatn, A. L., Bradley, B. H., \& Barrick, M. R. (2008, Feb). CEO transformational leadership: The role of goal importance congruence in top management teams. Academy of Management Journal, 51(1), 81-96. $<$ Go to ISI>://WOS:000254219100005

Conz, E., \& Magnani, G. (2020, Jun). A dynamic perspective on the resilience of firms: A systematic literature review and a framework for future research. European Management Journal, 38(3), 400-412. https://doi.org/10.1016/j.emj.2019.12.004

Cortes, A. F., \& Herrmann, P. (2021, Apr). Strategic leadership of innovation: A framework for future research [Article]. International Journal of Management Reviews, 23(2), 224-243. https://doi.org/10.1111/ijmr.12246

Crossan, M., Vera, D., \& Nanjad, L. (2008, Oct). Transcendent leadership: Strategic leadership in dynamic environments. Leadership Quarterly, 19(5), 569-581. https://doi.org/10.1016/j.leaqua.2008.07.008

Daft, R. L. (1978). A dual-core model of organizational innovation. The Academy of Management Journal, 21, $193-210$. https://doi.org/10.2307/255754

Dalton, D. R., \& Aguinis, H. (2013). Measurement Malaise in strategic management studies. Organizational Research Methods, 16(1), 88-99. https://doi.org/10.1177/1094428112470846

Ebrahimpour Azbari, M., Akbari, M., \& Hooshmand Chaijani, M. (2015). The Effect of strategic leadership and empowerment on job satisfaction of the employees of Guilan University. International Journal of Organizational Leadership, 4(4), 453-464. https://doi.org/10.33844/ijol.2015.60230

Elenkov, D. S., Judge, W., \& Wright, P. (2005, Jul). Straegic leadership and executive innovation influence: An international multi-cluster comparative study. Strategic Management Journal, 26(7), 665-682. https://doi.org/10.1002/smj.469 
Elenkov, D. S., \& Manev, I. M. (2005, Jun). Top management leadership and influence on innovation: The role of sociocultural context. Journal of Management, 31(3), 381-402. https://doi.org/10.1177/0149206304272151

Ensley, M. D., Hmieleski, K. M., \& Pearce, C. L. (2006, Jun). The importance of vertical and shared leadership within new venture top management teams: Implications for the performance of startups. Leadership Quarterly, 17(3), $217-231$. https://doi.org/10.1016/j.leaqua.2006.02.002

Finkelstein, S., Hambrick, D., \& Cannella, A. A. J. S. P. W. E. P. (1996). Strategic leadership. St. Paul: West Educational Publishing.

Frambach, R. T., \& Schillewaert, N. (2002). Organizational innovation adoption: a multi-level framework of determinants and opportunities for future research. Journal of Business Research, 55(2).

Glenn, R. W. (2001). Creating wealth in organizations: The role of strategic leadership. The Academy of Management Executive, 15(1).

Hambrick, D. C. (2007, Apr). Upper echelons theory: An update [Editorial Material]. Academy of Management Review, 32(2), 334-343. https://doi.org/10.5465/amr.2007.24345254

Hambrick, D. C., Finkelstein, S., \& Mooney, A. C. (2005, Jul). Executive job demands: New insights for explaining strategic decisions and leader behaviors. Academy of Management Review, 30(3), 472-491. < Go to ISI>://WOS:000230129100001

Hambrick, D. C., \& Mason, P. A. (1984). Upper Echelons: The organization as a reflection of its top managers. Academy of Management Review, 9, 193-206. https://doi.org/10.5465/AMR.1984.4277628

Hannan, M. T., \& Freeman, J. (1984). Structural inertia and organizational change. Sociological Review, 49, $149-164$. https://doi.org/10.2307/2095567

Hosmer, L. T. (1982). The importance of strategic leadership. The Journal of business strategy, 3(2), $47-57$. https://doi.org/10.1108/eb038966

House, R. J., \& Aditya, R. N. (1997). The social scientific study of leadership: Quo Vadis? Journal of Management, 23(3).

Huber, G. P. (1991). Organizational learning: The contributing processes and the literatures. Organization Science, 2(1).

Ireland, R. D., \& Hitt, M. A. (1999). Achieving and maintaining strategic competitiveness in the 21st century: The role of strategic leadership. Academy of Management Perspectives, 13, 43-57. https://doi.org/10.5465/AME.1999.1567311

Ireland, R. D., \& Hitt, M. A. (2005, Nov). Achieving and maintaining strategic competitiveness in the 21(st) century: The role of strategic leadership. Academy of Management Executive, 19(4), 63-77. https://doi.org/10.5465/ame.2005.19417908

Jansen, J. J. P., Vera, D., \& Crossan, M. (2009, Feb). Strategic leadership for exploration and exploitation: The moderating role of environmental dynamism. Leadership Quarterly, 20(1), 5-18. https://doi.org/10.1016/j.leaqua.2008.11.008

Ladkin, D. (2008, Feb). Leading beautifully: How mastery, congruence and purpose create the aesthetic of embodied leadership practice. Leadership Quarterly, 19(1), 31-41. https://doi.org/10.1016/j.leaqua.2007.12.003

Ling, Y., Simsek, Z., Lubatkin, M. H., \& Veiga, J. F. (2008). Transformational leadership's role in promoting corporate entrepreneurship: Examining the CEO-TMT interface. Academy of Management Journal, 51(3), 557-576. https://doi.org/10.5465/amj.2008.32626023

Luciano, M. M., Nahrgang, J. D., \& Shropshire, C. (2020, Jul). Strategic leadership systems: Viewing top management teams and boards of directors from a multiteam systems perspective. Academy of Management Review, 45(3), 675-701. https://doi.org/10.5465/amr.2017.0485

Ma, S., \& Seidl, D. (2018, Mar). New CEOs and their collaborators: Divergence and convergence between the strategic leadership constellation and the top management team. Strategic Management Journal, 39(3), 606-638. https://doi.org/10.1002/smj.2721

Martin, M. J., Aupperle, K. E., \& Chen, R. (1996). Strategic leadership and skill usage by academic presidents. Journal of Leadership \& Organizational Studies, 3(1).

Mayer, D. M., Kuenzi, M., Greenbaum, R., Bardes, M., \& Salvador, R. (2009). How low does ethical leadership flow? Test of a trickle-down model. Organizational Behavior and Human Decision Processes, 108(1).

Menz, M. (2012, Jan). Functional top management team members: A review, synthesis, and research agenda. Journal of Management, 38(1), 45-80. https://doi.org/10.1177/0149206311421830

Nemanich, L. A., \& Vera, D. (2009, Feb). Transformational leadership and ambidexterity in the context of an acquisition. Leadership Quarterly, 20(1), 19-33. https://doi.org/10.1016/j.leaqua.2008.11.002

Oke, A., Munshi, N., \& Walumbwa, F. O. (2009, Jan-Mar). The influence of leadership on innovation processes and activities. Organizational Dynamics, 38(1), 64-72. https://doi.org/10.1016/j.orgdyn.2008.10.005

Politis, D. (2005, Jul). The process of entrepreneurial learning: A conceptual framework. Entrepreneurship Theory and Practice, 29(4), 399-424. https://doi.org/10.1111/j.1540-6520.2005.00091.x 
Qian, Y. (1995). Reform of corporate governance structure and financing structure. Economic Research Journal, (01), 2029.

Resick, C. J., Whitman, D. S., Weingarden, S. A., \& Hiller, N. J. (2009, Nov). The bright-side and the dark-side of CEO personality: Examining core self-evaluations, narcissism, transformational leadership, and strategic influence. Journal of Applied Psychology, 94(6), 1365-1381. https://doi.org/10.1037/a0016238

Simsek, Z., Heavey, C., \& Fox, B. C. (2018, Jan). Interfaces of strategic leaders: A conceptual framework, review, and research agenda. Journal of Management, 44(1), 280-324. https://doi.org/10.1177/0149206317739108

Sosik, J. J., Jung, D. I., Berson, Y., Dionne, S. D., \& Jaussi, K. S. (2005). Making all the right connections:: The strategic leadership of top executives in high-tech organizations. Organizational Dynamics, 34(1), 47-61. https://doi.org/https://doi.org/10.1016/j.orgdyn.2004.11.003

Stoker, J. I., Grutterink, H., \& Kolk, N. J. (2012). Do transformational CEOs always make the difference? The role of TMT feedback seeking behavior. The Leadership Quarterly, 23(3).

Trahms, C. A., Ndofor, H. A., \& Sirmon, D. G. (2013, Jul). Organizational decline and turnaround: A review and agenda for future research. Journal of Management, 39(5), 1277-1307. https://doi.org/10.1177/0149206312471390

Vera, D., \& Crossan, M. (2004, Apr). Strategic leadership and organizational learning. Academy of Management Review, 29(2), 222-240. < Go to ISI >:/WOS:000220575500004

Waldman, D. A., Javidan, M., \& Varella, P. (2004, Jun). Charismatic leadership at the strategic level: A new application of upper echelons theory. Leadership Quarterly, 15(3), 355-380. https://doi.org/10.1016/j.leaqua.2004.02.013

Waldman, D. A., Siegel, D. S., \& Javidan, M. (2006, Dec). Components of CEO transformational leadership and corporate social responsibility. Journal of Management Studies, 43(8), 1703-1725. https://doi.org/10.1111/j.14676486.2006.00642.x

Wang, H., Tsui, A. S., \& Xin, K. R. (2011, Feb). CEO leadership behaviors, organizational performance, and employees' attitudes. Leadership Quarterly, 22(1), 92-105. https://doi.org/10.1016/j.leaqua.2010.12.009

Yukl, G. (2008, Dec). How leaders influence organizational effectiveness. Leadership Quarterly, 19(6), $708-722$. https://doi.org/10.1016/j.leaqua.2008.09.008

Zhang, X. A., Li, N., Ullrich, J., \& van Dick, R. (2015, Nov). Getting everyone on board: The effect of differentiated transformational leadership by CEOs on top management team effectiveness and leader-rated firm performance. Journal of Management, 41(7), 1898-1933. https://doi.org/10.1177/0149206312471387

Zheng, Z. (2004). Review of the literature on the theory of corporate governance mechanisms Nankai Economic Studies, (05), 26-33.

Zhu, W. C., Chew, I. K. H., \& Spangler, W. D. (2005, Feb). CEO transformational leadership and organizational outcomes: The mediating role of human-capital-enhancing human resource management. Leadership Quarterly, 16(1), 39-52. https://doi.org/10.1016/j.leaqua.2004.06.001

\section{Acknowledgements}

Not applicable.

\section{Disclosure Statement}

No potential conflict of interest was reported by the authors.

\section{Funding Acknowledgements}

This research is supported by Grant No. 71832006 from the National Natural Science Foundation of China.

\section{Open Access}

The International Journal of Organizational Leadership publishes open access articles under the terms of the Creative Commons Attribution (CC BY) License, which permits use, distribution, and reproduction in any medium, provided the original work is properly cited. 